\title{
DISTRIBUTION OF $\mathrm{Al}_{2} \mathrm{O}_{3}$ REINFORCEMENT PARTICLES IN AUSTENITIC STAINLESS STEEL DEPENDING ON THEIR SIZE AND CONCENTRATION
}

\author{
PORAZDELITEV DELCEV $\mathrm{Al}_{2} \mathrm{O}_{3} \mathrm{~V}$ AVSTENITNEM NERJAVNEM \\ JEKLU V ODVISNOSTI OD VELIKOSTI IN KONCENTRACIJE
}

\author{
Ana Kračun ${ }^{1,2}$, Bojan Podgornik ${ }^{1}$, Franc Tehovnik ${ }^{1}$, Fevzi Kafexhiu ${ }^{1}$, \\ Darja Jenko ${ }^{1}$ \\ Institute of Metals and Technology, Lepi pot 11, 1000 Ljubljana, Slovenia \\ ${ }^{2}$ Jožef Stefan International Postgraduate School, Jamova cesta 39, 1000 Ljubljana, Slovenia \\ ana.kracun@imt.si \\ Prejem rokopisa - received: 2017-04-13; sprejem za objavo - accepted for publication: 2017-09-22
}

doi:10.17222/mit.2017.042

\begin{abstract}
Achieving a uniform distribution of reinforcement particles within a matrix is one of the challenges that impacts directly on the properties and quality of a composite material. Therefore, the aim of the present work was to investigate the influence of the reinforcing $\mathrm{Al}_{2} \mathrm{O}_{3}$ particles' concentration and size on their distribution in reinforced austenite stainless steel. Austenitic stainless steel reinforced with $(0.5,1.0$ and 2.5$) \%$ of mass fractions of $\mathrm{Al}_{2} \mathrm{O}_{3}$ particles was produced by a conventional casting route. In this study, an innovative pre-dispersion approach for the addition of particles into a steel melt was designed. The results of this investigation indicate that the concentration and size of the $\mathrm{Al}_{2} \mathrm{O}_{3}$ particles has an impact on the distribution of the reinforcement within the matrix. When the weight percent increased to 2.5 the concentration ratio of the particles' distribution decreases towards the bottom of the cast ingot. In this case also the size of particles starts to play a role, with the larger particle size leading to an increased degree of incorporating particles into the steel matrix. The larger the particles the more particles are found in the cast ingot.

Keywords: metal matrix composite, reinforced particles, distribution, conventional casting method
\end{abstract}

Doseganje enakomerne porazdelitve delcev v matrici je eden izmed izzivov, ki direktno vplivajo na lastnosti in kvaliteto kompozitnih materialov. Namen raziskave je bil ugotoviti porazdelitev delcev v mikrostrukturi jekla glede na dodano koncentracijo in velikost. Med procesom konvencionalnega litja avstenitnega nerjavnega jekla so bili dodani delci $\mathrm{Al}_{2} \mathrm{O}_{3} \mathrm{v}$ utežnih procentih $(0,5,1,0$ in 2,5$)$. V tej študiji smo uporabili inovativni pristop dispergiranja delcev pred dodajanjem $\mathrm{v}$ jekleno talino. Rezultati raziskave kažejo, da je koncentracija in velikost $\mathrm{Al}_{2} \mathrm{O}_{3}$ delcev vplivala na porazdelitev delcev $\mathrm{v}$ matrici. $\mathrm{S}$ povečanjem utežnega procenta dodanih delcev na 2,5 se je koncentracijsko razmerje delcev zmanjšalo proti dnu ulitega ingota. $\mathrm{V}$ tem primeru ima pomemben vpliv na porazdelitev tudi velikost delcev, večji kot so delci več jih je vključenih v matrico. Večji kot so delci, več se jih nahaja v ulitem ingotu.

Ključne besede: kovinski kompoziti, utrjevalni delci, porazdelitev, metoda konvencionalnega litja

\section{INTRODUCTION}

The application of metal-matrix composites (MMCs) as structural engineering materials has received increasing attention in recent years. ${ }^{1-3}$ Ceramic particulates such as borides, carbides, oxides and nitrides are added to MMCs to improve their elastic modulus, wear resistance, creep and strength. ${ }^{4-5}$

There are different routes by which MMCs can be manufactured, and among all the liquid-stat processes are considered to have the most potential for engineering applications in terms of production capacity and cost efficiency. Casting techniques are economical, easier to apply and more convenient for large parts and mass production with regard to other manufacturing techniques. However, it is extremely difficult to obtain a uniform dispersion of ceramic nanoparticles in liquid metals due to the poor wettability and to the difference in specific gravity between the ceramic particles and the metal matrix. ${ }^{6-8}$
The current work aims at contributing to the knowledge and understanding of the conventional casting route and its possibility for ultrafine particle inoculation in a steel matrix. This production route seems to show potential and offers more cost efficiency in achieving the dispersion of second-phase ultrafine range particles compared to the typically used powder and metallurgical techniques used until now. The aim of the present work is to identify the distribution of particles in the steel matrix that were introduced through a conventional melting and casting method, and above all to determine the influence of the different concentrations, sizes and methods of adding $\mathrm{Al}_{2} \mathrm{O}_{3}$ particles on the distribution of the latter in reinforced austenite stainless steel. In terms of the methods the focus was on the influence of dispersion medium CaSi $(\mathrm{Ca}-30 \%$, Si-70 \%) on the distribution homogeneity of the $\mathrm{Al}_{2} \mathrm{O}_{3}$ particles. 
A. KRAČUN et al.: DISTRIBUTION OF $\mathrm{Al}_{2} \mathrm{O}_{3}$ REINFORCEMENT PARTICLES IN AUSTENITIC STAINLESS STEEL ...

\section{EXPERIMENTAL PART}

\subsection{Material}

Austenitic stainless steel has been used for the work, mainly due to its distinctive two-phase microstructure of austenite and ferrite. It also belongs to the most used group of stainless steels. They are paramagnetic, have a face-centred cubic lattice and excel with a good combination of hot and cold workability, mechanical properties and corrosion resistance. The chemical composition of the base alloy is given in Table $\mathbf{1}$.

Table 1: Chemical composition of austenitic stainless steel in weight percent $(w / \%)$

\begin{tabular}{|c|c|}
\hline Elements & $w / \%$ \\
\hline $\mathrm{Si}$ & 0.33 \\
\hline $\mathrm{Mn}$ & 1.24 \\
\hline $\mathrm{Cr}$ & 17.4 \\
\hline $\mathrm{Ni}$ & 10.1 \\
\hline $\mathrm{Cu}$ & 0.36 \\
\hline $\mathrm{Mo}$ & 1.29 \\
\hline $\mathrm{V}$ & 0.08 \\
\hline $\mathrm{C}$ & 0.02 \\
\hline
\end{tabular}

As reinforcement particles, commercial $\mathrm{Al}_{2} \mathrm{O}_{3}$ powder from the company US Research Nanomaterials, Inc. with a mean particle size of $500 \mathrm{~nm}$ (Figure 1) and $50 \mathrm{~nm}$ (Figure 2) was used. The $\mathrm{Al}_{2} \mathrm{O}_{3}$ particles were selected due to their high chemical stability with respect to $\mathrm{Fe}$ and high specific gravity. Particularly, it was reported that the wetting angle $\Theta$ between $\mathrm{Al}_{2} \mathrm{O}_{3}$ and molten iron alloy is less than $50^{\circ}$, even at high temperatures and in many different types of atmospheres. ${ }^{9}$

As a dispersion medium CaSi (Ca-30 \%, Si-70 \%) was used. Ca additions are made during steel making for refining, deoxidation, desulphurization, and control of the shape, size and distribution of oxide and sulphide inclusions. However, elemental $\mathrm{Ca}$ is difficult and dangerous to add to liquid steel because it has a high reacti vity. ${ }^{10}$ Therefore, $\mathrm{Ca}$ in the stabilized forms of calcium silicon $(\mathrm{CaSi})$, calcium manganese silicon $(\mathrm{CaMnSi})$,

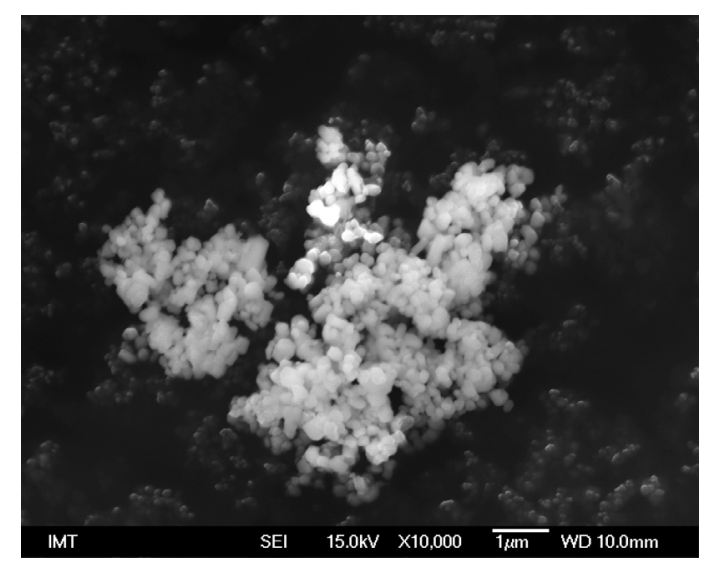

Figure 1: SEI of ultrafine $\mathrm{Al}_{2} \mathrm{O}_{3}$ powder with a mean particle size of $500 \mathrm{~nm}$ calcium silicon barium ( $\mathrm{CaSiBa})$ and calcium silicon barium aluminium ( $\mathrm{CaSiBaAl})$ alloys or as calcium carbide $\left(\mathrm{CaC}_{2}\right)$ is used. In the present work $\mathrm{CaSi}$ was used due to the fact that it is most commonly used as deoxidant element in steelmaking, and does not cause contamination of the steel melt. The aim of the CaSi addition was to control the shape, size and distribution of oxide particles added in the steel melt.

\subsection{Specimens preparation}

First a weighed quantity (14 kg) of austenitic stainless steel was melted in the open induction furnace (TYP SF $70 \mathrm{sl}$ ) with a generator under normal atmospheric conditions. The maximum temperature of the melt production is up to $1750{ }^{\circ} \mathrm{C}$. In the first set of experiments six different batches were prepared using two different particle sizes $(500 \mathrm{~nm}$ and $50 \mathrm{~nm})$ and three different concentrations $(0.5,1.0$ and 2.5$) \%$ of mass fractions of $\mathrm{Al}_{2} \mathrm{O}_{3}$, as shown in Table 2. The $\mathrm{Al}_{2} \mathrm{O}_{3}$ particles powder was wrapped into the aluminium foil, placed into the mould and then the molten metal was poured over it into the mould. During casting the aluminium foil melts and dissolves in the metal.

Table 2: Addition scheme for the first set of experiments $-\mathrm{Al}_{2} \mathrm{O}_{3}$ particles size and concentration used.

\begin{tabular}{|c|c|c|}
\hline \multirow{2}{*}{} & \multicolumn{2}{|c|}{$\mathrm{Al}_{2} \mathrm{O}_{3}$ particle size } \\
\cline { 2 - 3 } & $500 \mathrm{~nm}$ & $50 \mathrm{~nm}$ \\
\hline \multirow{3}{*}{$\begin{array}{c}\text { Concentrations } \\
(w / \%)\end{array}$} & 0.5 & 0.5 \\
\cline { 2 - 3 } & 1.0 & 1.0 \\
\cline { 2 - 3 } & 2.5 & 2.5 \\
\hline
\end{tabular}

The second set of experiments comprised four batches where two different $\mathrm{Al}_{2} \mathrm{O}_{3}$ particle sizes $(500 \mathrm{~nm}$ and $50 \mathrm{~nm}$ ) in weight percent of 1.0 were used. In two cases the $\mathrm{Al}_{2} \mathrm{O}_{3}$ powder was mixed with the same amount of dispersion media - CaSi (Ca $30 \%$, Si $70 \%)$ and filled into a cast-iron tube. For comparison two additional batches were prepared where only $\mathrm{Al}_{2} \mathrm{O}_{3}$ powder sealed into a cast iron tube was used, Table 3. The cast-iron

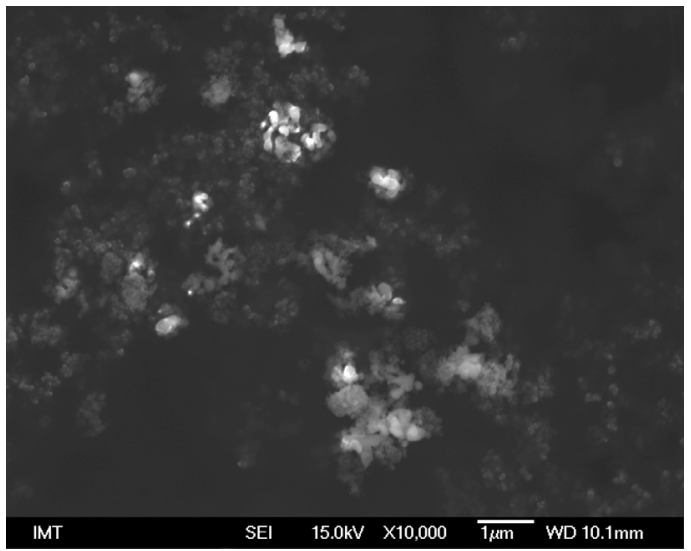

Figure 2: SEI of $\mathrm{Al}_{2} \mathrm{O}_{3}$ nanopowder with a mean particle size of $50 \mathrm{~nm}$ 


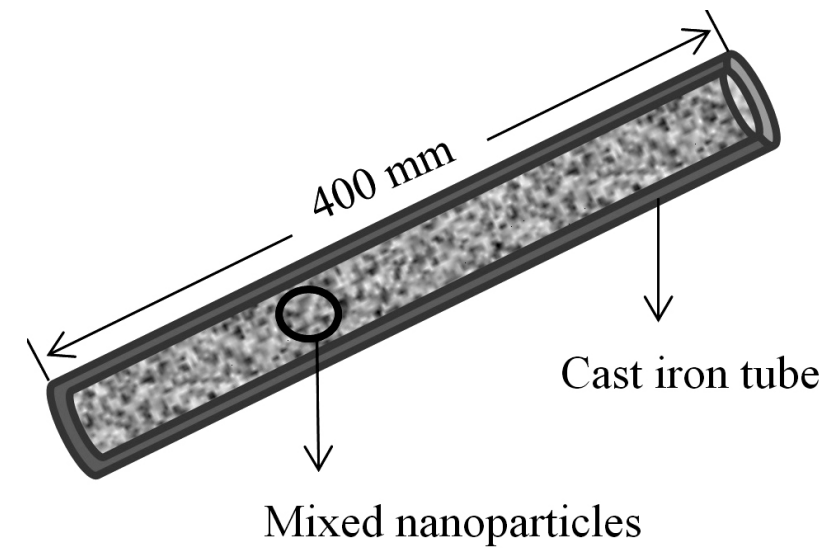

Figure 3: Schematic diagram of a cast-iron tube, filled with nanoparticles

tube had a length of $400 \mathrm{~mm}$, outer diameter $12 \mathrm{~mm}$ and wall thickness $2 \mathrm{~mm}$, as shown in Figure 3. The ends of the tube were sealed with pliers and the molten metal was poured over the iron tube into the mould. The iron tube melts and dissolves in the melt.

Table 3: Addition scheme for the second set of experiments $-\mathrm{Al}_{2} \mathrm{O}_{3}$ particles mixed with $\mathrm{CaSi}$ and dispersion medium.

\begin{tabular}{|c|c|c|}
\hline \multirow{2}{*}{} & \multicolumn{2}{|c|}{$\mathrm{Al}_{2} \mathrm{O}_{3}$ particle size } \\
\cline { 2 - 3 } & $500 \mathrm{~nm}(1.0 \%)$ & $50 \mathrm{~nm}(1.0 \%)$ \\
\hline $\begin{array}{c}\text { Dispersion medium } \\
(\mathrm{CaSi})(w / \%)\end{array}$ & 1 & 1 \\
\cline { 2 - 3 } & 0 & 0 \\
\hline
\end{tabular}

\subsection{Characterization}

The microstructural changes and the dispersion of the ceramic particles in the steel matrix were observed and analysed by light microscopy (LM), scanning electron microscopy (SEM), Auger electron spectroscopy (AES) and transmission electron microscopy (TEM). Samples for the microstructure analysis were taken at the bottom, middle and top portions of the cast ingot, Figure 4 . Metallographic samples were prepared by grinding and polishing, followed by chemical etching and analysed to reveal the particle distribution. In the case of AES ground and polished specimens were ion sputtered and analysed in terms of the elemental composition in the surface region. Samples for TEM were prepared by slicing the specimens into thin $0.5-1.0$-mm-thick plates with a length of up to $3 \mathrm{~mm}$. After polishing to a thickness of $100 \pm 10 \mu \mathrm{m}$, final milling of the specimen was carried out with an ion slicer.

For a representative analysis of the particles' distribution, three specimens located at different positions within the ingot diameter were prepared for each position (top-G, middle-S, bottom-N) and ten images taken with a scanning electron microscope for each sample and position. In order to do particle analysis efficiently, all images were taken at the same magnification $(1000 \times)$ with similar contrast. Then ImageJ commercial software

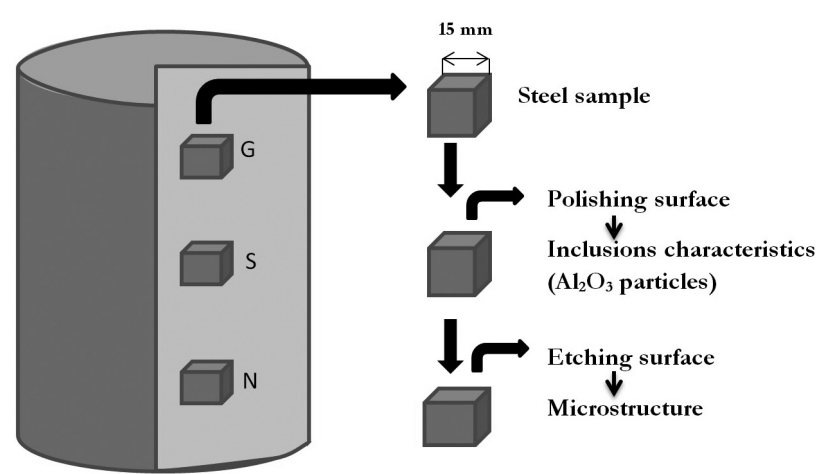

Figure 4: Schematic diagram of subtraction and preparation of metallographic steel samples

was used to calculate and determine the particles distribution and their volume fraction.

\section{RESULTS AND DISCUSSION}

\subsection{Light microscopy (LM)}

Figure 5 shows a LM image of the microstructure of pure austenitic stainless steel with a distinctive twophase microstructure of austenite and $\delta$-ferrites obtained. LM micrographs of the microstructure with included ultrafine $\mathrm{Al}_{2} \mathrm{O}_{3}$ particles; produced by the casting process where the melted austenitic stainless steel was poured over the $\mathrm{Al}_{2} \mathrm{O}_{3}$ particles wrapped into the $\mathrm{Al}$ foil is shown in Figure 6 and 7.

It is clear that the distribution of $\mathrm{Al}_{2} \mathrm{O}_{3}$ particles with a mean particle size of $500 \mathrm{~nm}$ is non-homogeneous and concentrated in several isolated areas (Figure 6). However, the distribution of $\mathrm{Al}_{2} \mathrm{O}_{3}$ particles with a mean particle size of $50 \mathrm{~nm}$, shown in Figure 7, is more homogeneous with reduced clustering of the particles, as compared to the 500-nm particles size case.

From the light micrographs in Figures 8 and 9 we can see that the distribution of ultrafine $\mathrm{Al}_{2} \mathrm{O}_{3}$ particles from the second set of experiments, Table 3. Distribution

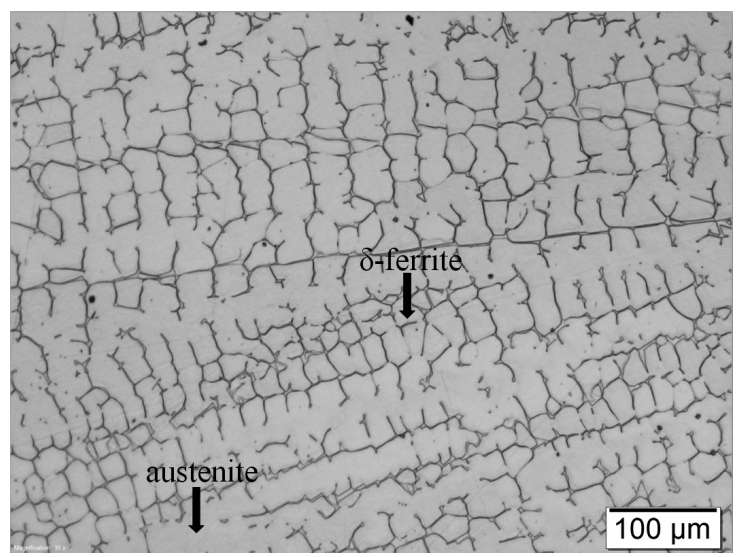

Figure 5: Cast microstructure of austenitic stainless steel with $6 \%$ of $\delta$-ferrite 
A. KRAČUN et al.: DISTRIBUTION OF $\mathrm{Al}_{2} \mathrm{O}_{3}$ REINFORCEMENT PARTICLES IN AUSTENITIC STAINLESS STEEL ...

of $\mathrm{Al}_{2} \mathrm{O}_{3}$ particles (white arrows) is more homogeneous and not concentrated in certain areas. Furthermore, clustering of the particles is smaller than in the first set of experiments without using the $\mathrm{CaSi}$.

As shown in Figures 10 and 11, the microstructure of austenitic stainless steel and the distribution of the in-

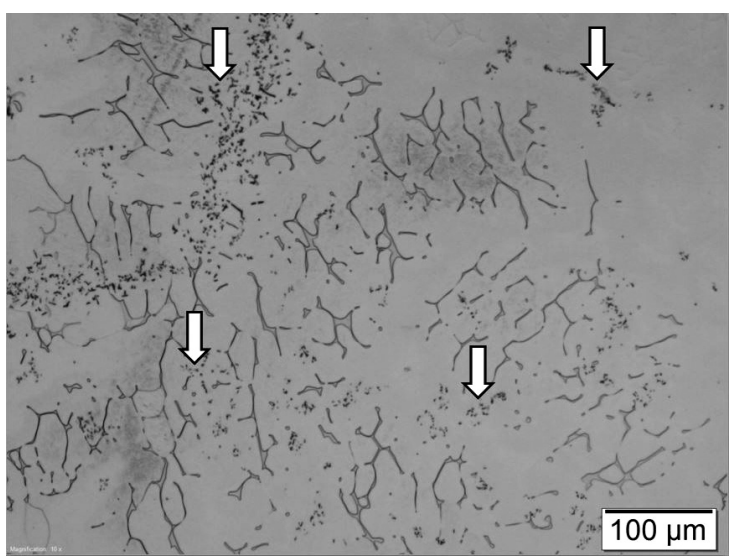

Figure 6: Cast microstructure of austenitic stainless steel with $6 \%$ of $\delta$-ferrite and $\mathrm{Al}_{2} \mathrm{O}_{3}(500 \mathrm{~nm}, 1.0 \%)$ ultrafine particles (white arrows)

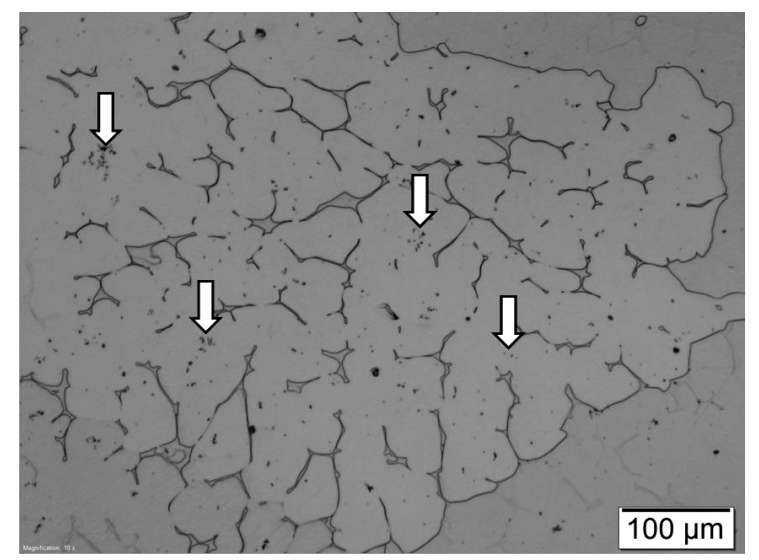

Figure 7: Cast microstructure of austenitic stainless steel with $6 \%$ of $\delta$-ferrite and $\mathrm{Al}_{2} \mathrm{O}_{3}(50 \mathrm{~nm}, 1.0 \%)$ nanoparticles (white arrows)

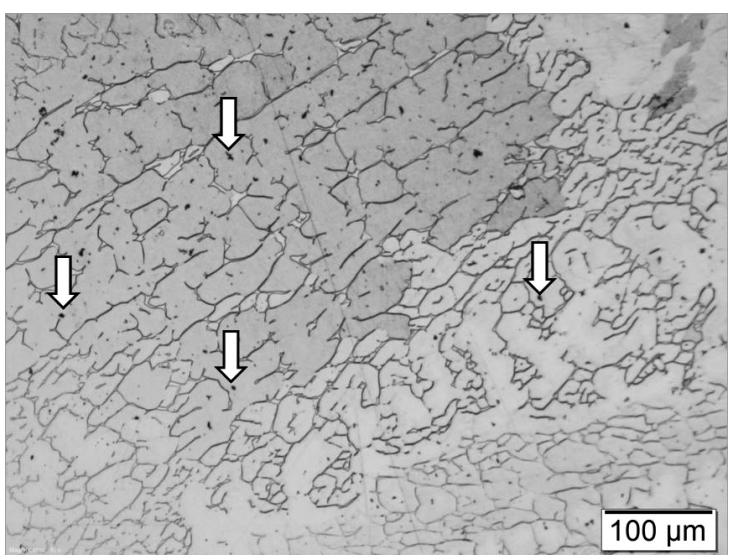

Figure 8: Cast microstructure of austenitic stainless steel with $6 \%$ of $\delta$-ferrite and $\mathrm{Al}_{2} \mathrm{O}_{3}(500 \mathrm{~nm}, 1.0 \%)$ ultrafine particles (white arrows) corporated nanosized particles is further modified when using $\mathrm{Al}_{2} \mathrm{O}_{3}$ particles mixed with $\mathrm{CaSi}$ dispersion media, from the second set of experiments, Table 3 . In this case the distribution of $\mathrm{Al}_{2} \mathrm{O}_{3}$ particles (white arrows) becomes much more homogeneous and almost equally distributed within the metal matrix. Furthermore, the

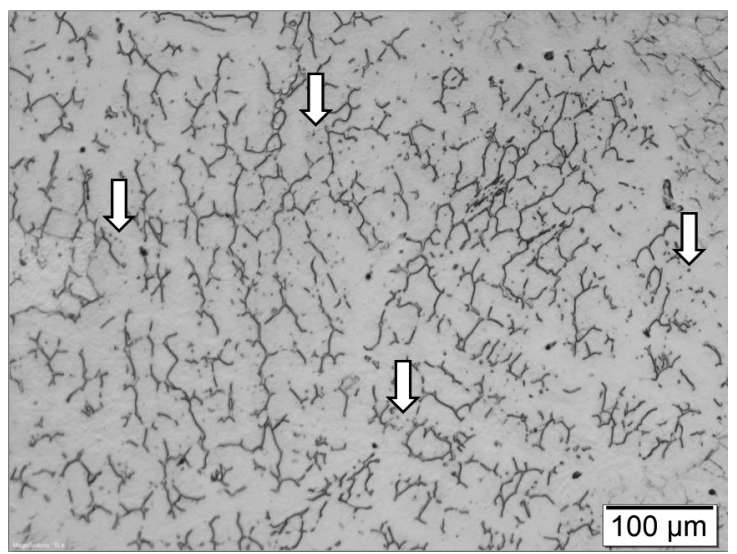

Figure 9: Cast microstructure of austenitic stainless steel with $6 \%$ of $\delta$-ferrite and $\mathrm{Al}_{2} \mathrm{O}_{3}$ particles (white arrows); ultrafine powder (500 nm, $1.0 \%)$ mixed with $\mathrm{CaSi}(\mathrm{Ca}-30 \%$, Si-70 \%)

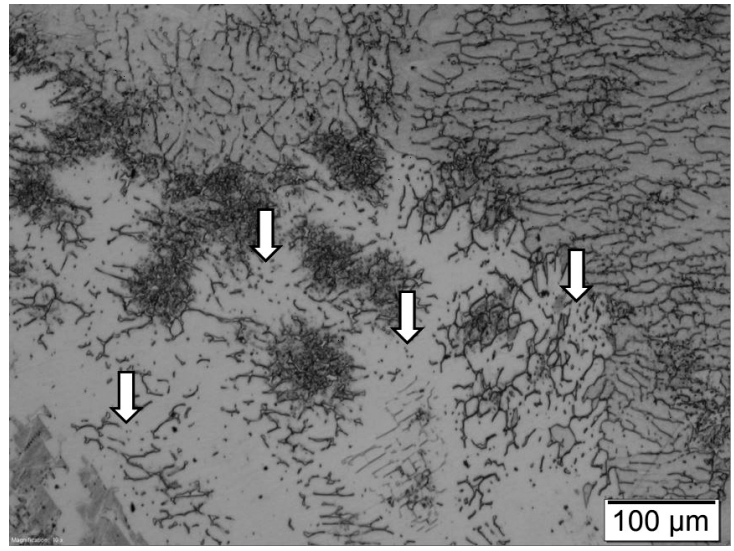

Figure 10: Cast microstructure of austenitic stainless steel with $6 \%$ of $\delta$-ferrite and $\mathrm{Al}_{2} \mathrm{O}_{3}(50 \mathrm{~nm}, 1.0 \%)$ nanoparticles (white arrows)

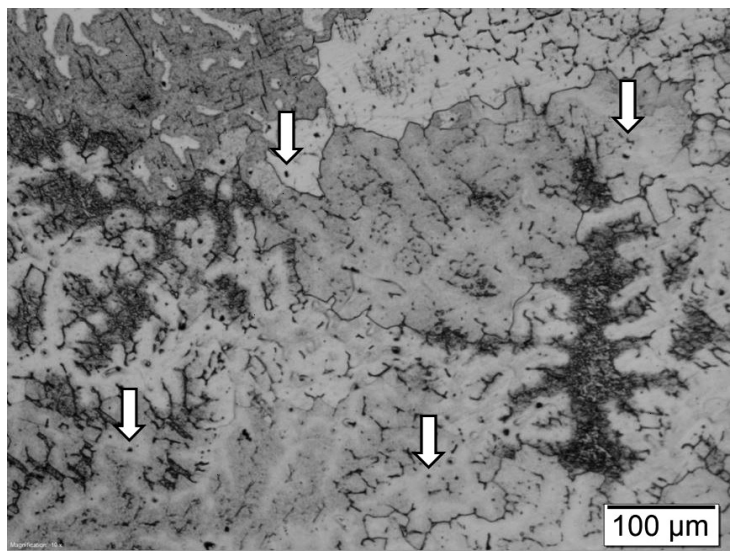

Figure 11: Cast microstructure of austenitic stainless steel with $6 \%$ of $\delta$-ferrite and $\mathrm{Al}_{2} \mathrm{O}_{3}$ nanoparticles (white arrows); nanoparticles powder $(50 \mathrm{~nm}, 1.0 \%)$ mixed with $\mathrm{CaSi}(\mathrm{Ca}-30 \%, \mathrm{Si}-70 \%)$ 
A. KRAČUN et al.: DISTRIBUTION OF $\mathrm{Al}_{2} \mathrm{O}_{3}$ REINFORCEMENT PARTICLES IN AUSTENITIC STAINLESS STEEL ...
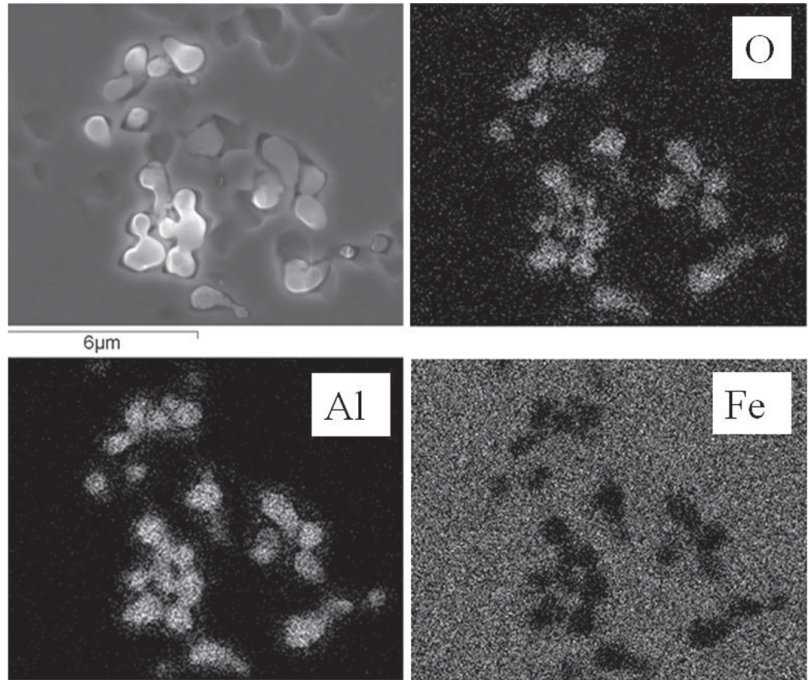

Figure 12: SEM/EDS elemental mapping of $\mathrm{Al}_{2} \mathrm{O}_{3}$ ultrafine particles $(500 \mathrm{~nm}, 1.0 \mathrm{~nm} \%)$ in the cast microstructure of austenitic stainless steel, from the first set of experiments, without using the CaSi

clustering of the particles reduced as compared to the first set of experiments, without using the CaSi.

A size-dependent analysis show that $\mathrm{Al}_{2} \mathrm{O}_{3}$ powder with a mean particle size $50 \mathrm{~nm}$ is more homogeneously distributed than the $500 \mathrm{~nm}$ powder. In the cases when we added the $\mathrm{CaSi}$ to $\mathrm{Al}_{2} \mathrm{O}_{3}$ the distribution of particles was more homogeneous in all three sampling areas (top-G, middle-S, bottom-N) of the cast ingot; from the top to the bottom of the cast ingot.

\subsection{Scanning electron microscopy (SEM)}

After the metallographic examination the specimens were subjected to SEM analysis in order to confirm the incorporation/presence of $\mathrm{Al}_{2} \mathrm{O}_{3}$ ultrafine particles in the microstructure and to analyse the particles clustering. From the SEM/EDS elemental mapping analysis, shown in the Figure 12, it was confirmed that the bright, small, spot-like features represent the $\mathrm{Al}_{2} \mathrm{O}_{3}$ ultrafine particles,

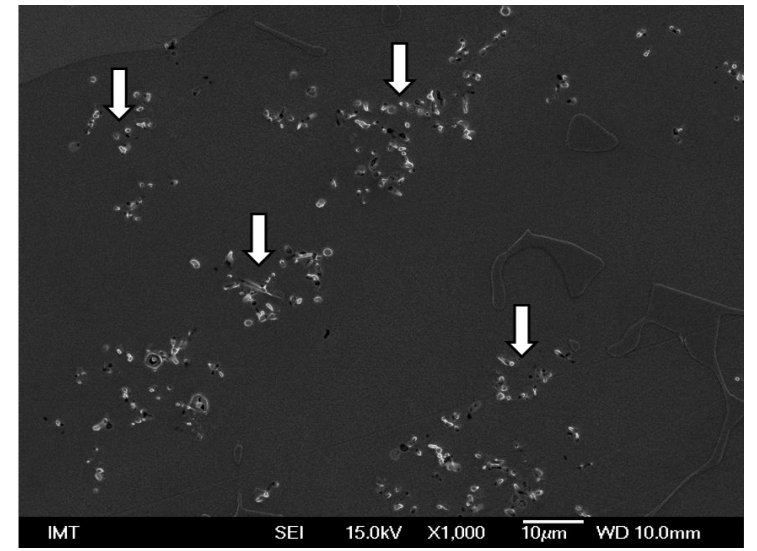

Figure 13: Cast microstructure of austenitic stainless steel with $6 \%$ of $\delta$-ferrite and $\mathrm{Al}_{2} \mathrm{O}_{3}(500 \mathrm{~nm}, 1.0 \%)$ ultrafine particles (white arrows), without using the $\mathrm{CaSi}$

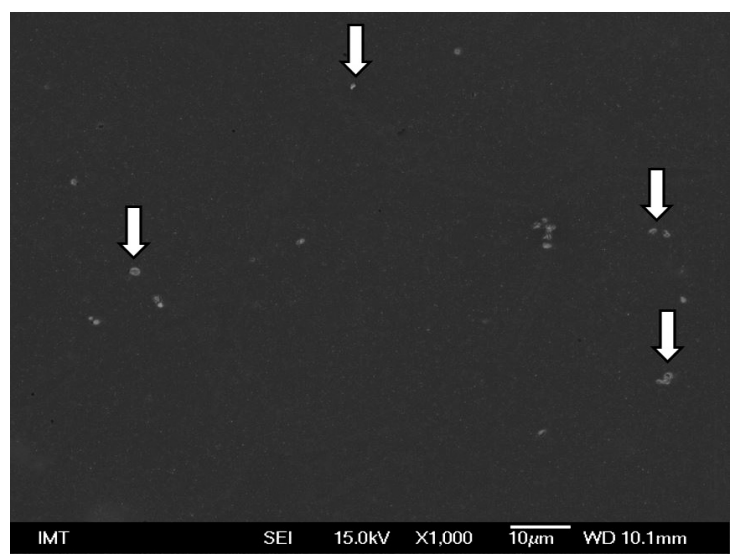

Figure 14: Cast microstructure of austenitic stainless steel with $6 \%$ of $\delta$-ferrite and $\mathrm{Al}_{2} \mathrm{O}_{3}$ particles (white arrows); ultrafine powder (500 nm, $1.0 \%)$ mixed with $\mathrm{CaSi}(\mathrm{Ca}-30 \%, \mathrm{Si}-70 \%)$
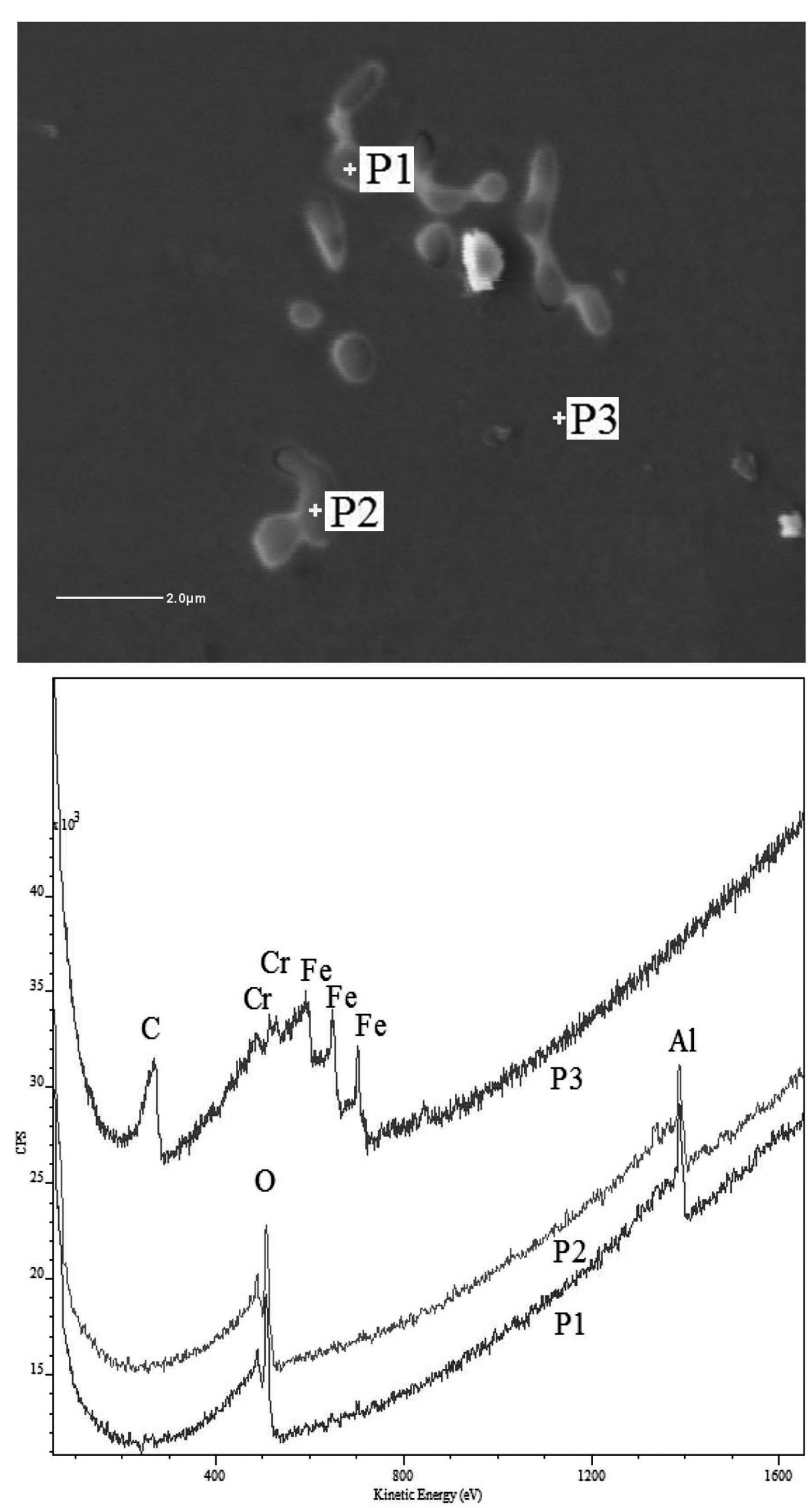

Figure 15: AES spectrum of the $\mathrm{Al}_{2} \mathrm{O}_{3}$ ultrafine particles $(500 \mathrm{~nm}$, $1.0 \%$ ) in the cast microstructure of austenitic stainless steel, without using the $\mathrm{CaSi}$ 


\section{MATERIALI IN TEHNOLOGIJE/MATERIALS AND TECHNOLOGY (1967-2017) - 50 LET/50 YEARS}

A. KRAČUN et al.: DISTRIBUTION OF $\mathrm{Al}_{2} \mathrm{O}_{3}$ REINFORCEMENT PARTICLES IN AUSTENITIC STAINLESS STEEL ...

which are incorporated but non-uniformly distributed in the steel matrix. Furthermore, a high degree of particles clustering was observed.

Concentration-dependent analysis shows that at the $0.5 \%$ to $1.0 \%$ of mass fractions of the distribution of particles is more homogeneous throughout the cast ingot than in the case of $2.5 \%$ of mass fractions. Size-dependent analysis show that $\mathrm{Al}_{2} \mathrm{O}_{3}$ powder with a mean particle size $50 \mathrm{~nm}$ is more homogeneously distributed than $500 \mathrm{~nm}$. The addition of CaSi plays an important role in case of distribution and clustering of $\mathrm{A}_{2} \mathrm{O}_{3}$ particles, as shown in Figures $\mathbf{1 3}$ and $\mathbf{1 4}$ where $\mathrm{Al}_{2} \mathrm{O}_{3}$ particles were mixed with $\mathrm{CaSi}$ dispersion media, from the second set of experiments, Table 3.

From Figures 13 and 14 we can see that distribution of $\mathrm{Al}_{2} \mathrm{O}_{3}$ particles (white arrows) becomes much more homogeneous and quite equally distributed within the metal matrix when using $\mathrm{CaSi}$ dispersion media.
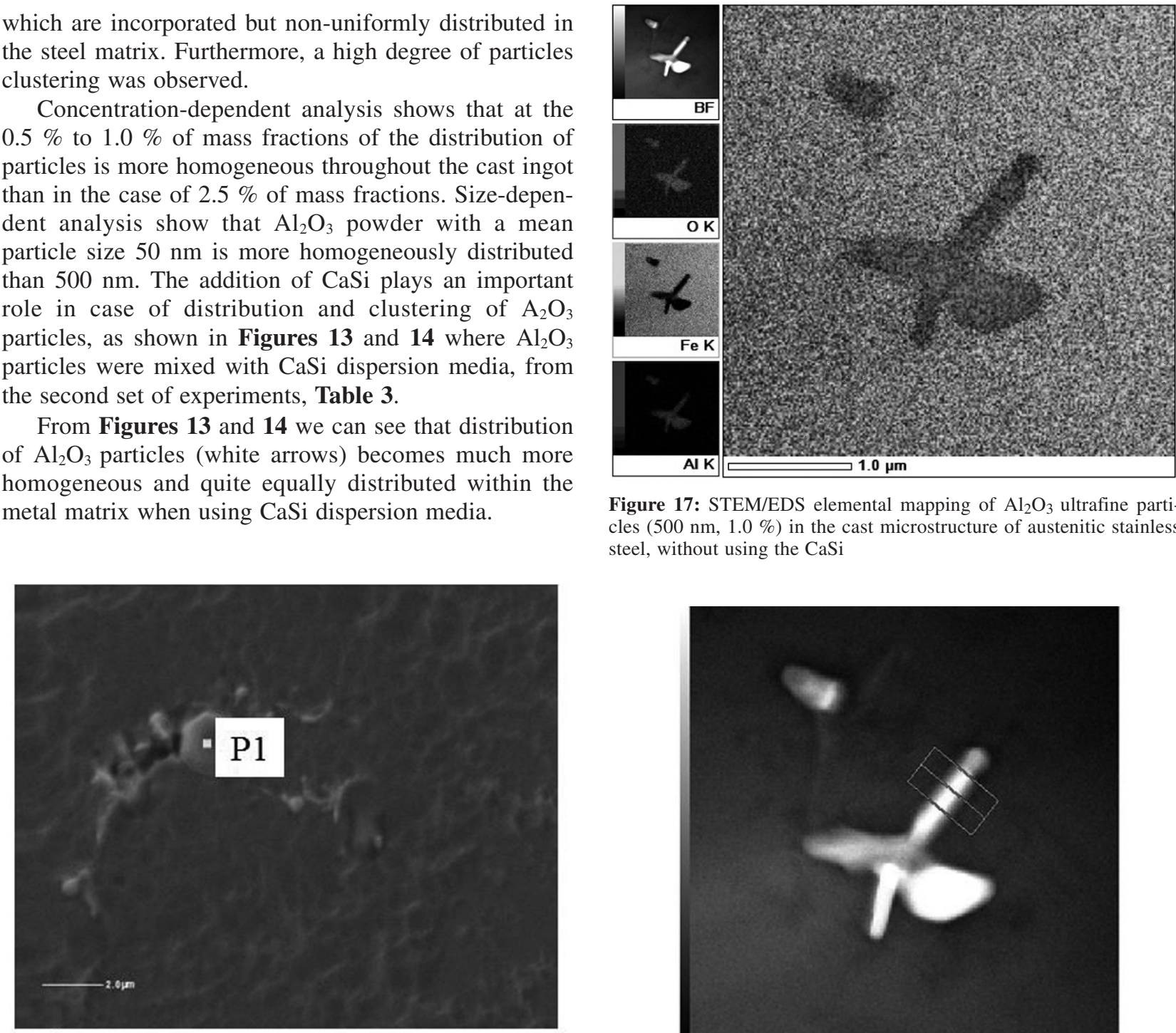

Figure 17: STEM/EDS elemental mapping of $\mathrm{Al}_{2} \mathrm{O}_{3}$ ultrafine particles $(500 \mathrm{~nm}, 1.0 \%)$ in the cast microstructure of austenitic stainless steel, without using the $\mathrm{CaSi}$
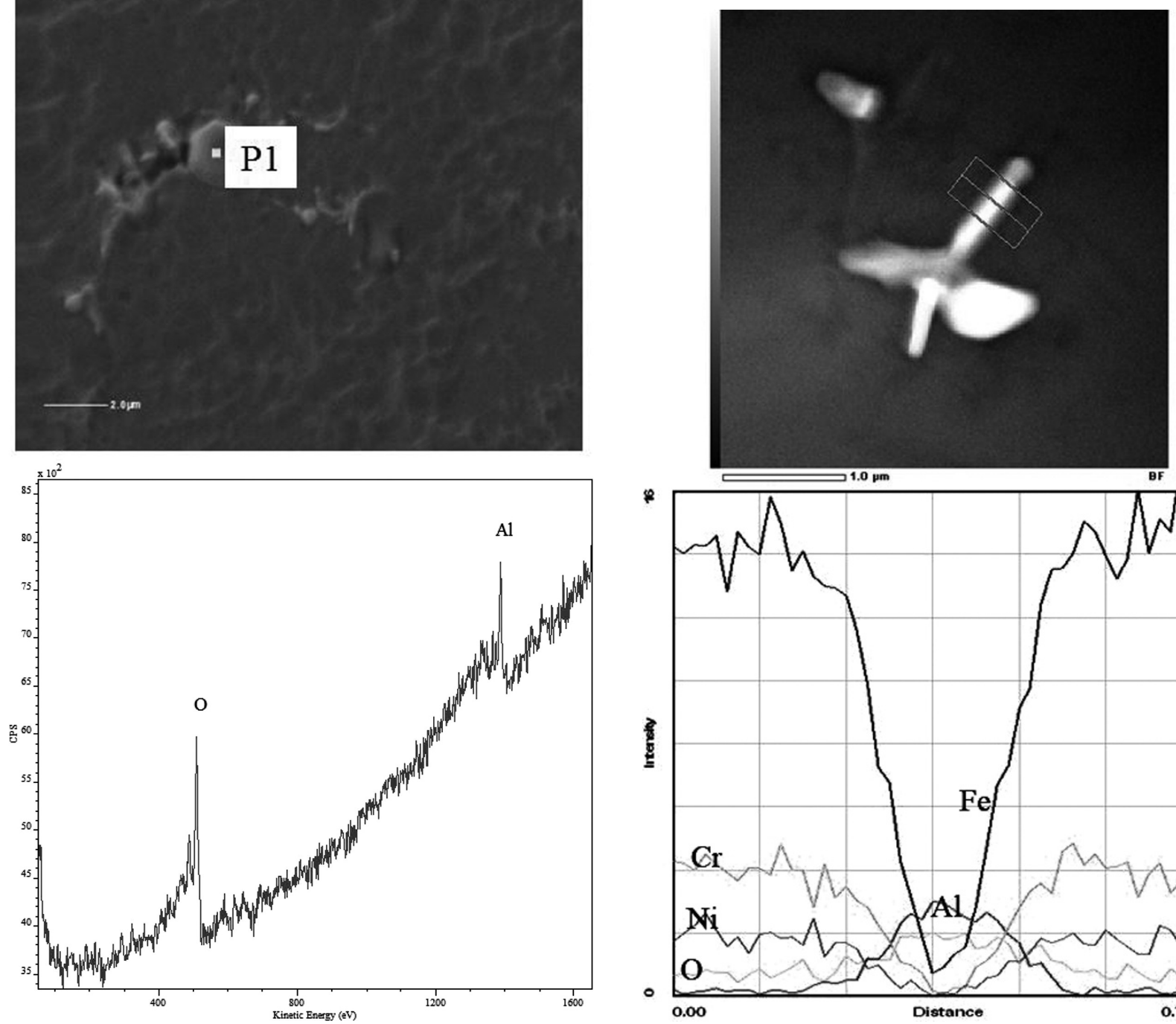

Figure 16: AES spectrum of the $\mathrm{Al}_{2} \mathrm{O}_{3}$ ultrafine particles $(500 \mathrm{~nm}$, $1.0 \%)$ mixed with $\mathrm{CaSi}(\mathrm{Ca}-30 \%, \mathrm{Si}-70 \%)$ in the cast microstructure of austenitic stainless steel

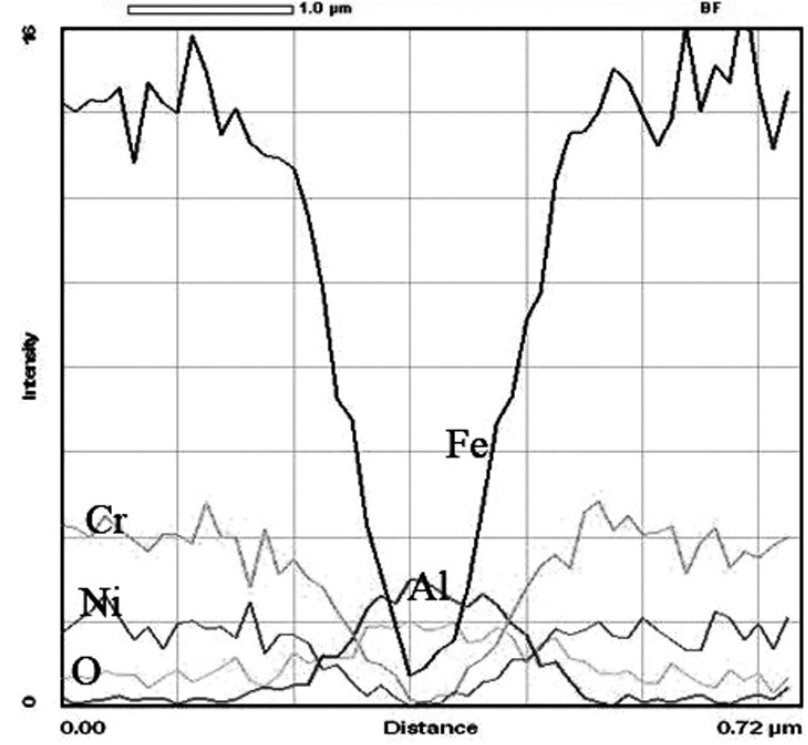

Figure 18: STEM - line profile of $\mathrm{Al}_{2} \mathrm{O}_{3}$ ultrafine particles $(500 \mathrm{~nm}$, $1.0 \%)$ in the cast microstructure of austenitic stainless steel, without using the $\mathrm{CaSi}$ 
A. KRAČUN et al.: DISTRIBUTION OF $\mathrm{Al}_{2} \mathrm{O}_{3}$ REINFORCEMENT PARTICLES IN AUSTENITIC STAINLESS STEEL ...

\subsection{Auger electron spectroscopy (AES)}

In the next step a surface analysis of the sample using Auger electron spectroscopy technique was performed. In Figure 15 the AES spectrum of the $\mathrm{Al}_{2} \mathrm{O}_{3}$ ultrafine particles $(500 \mathrm{~nm}, 1.0 \%)$ in the cast microstructure of austenitic stainless steel is shown. The AES spectra of particles ( $\mathrm{P} 1$ and $\mathrm{P} 2)$ showing only $\mathrm{O}$ and $\mathrm{Al}$ peaks and line scans over the particle/matrix interface confirm the successful introduction of $\mathrm{Al}_{2} \mathrm{O}_{3}$ particles into the steel matrix (P3) without any intermetallic reactions taking place, which is true for all the $\mathrm{Al}_{2} \mathrm{O}_{3}$ particle sizes and concentrations used. In Figure 16 the AES spectrum of the $\mathrm{Al}_{2} \mathrm{O}_{3}$ ultrafine particles $(500 \mathrm{~nm}, 1.0 \%)$ mixed with $\mathrm{CaSi}(\mathrm{Ca}-30 \%, \mathrm{Si}-70 \%)$ in the cast microstructure of the austenitic stainless steel is shown. The AES spectrum of particles (P1) shows only $\mathrm{O}$ and $\mathrm{Al}$ peaks. Also in cases when $\mathrm{CaSi}$ was added to $\mathrm{Al}_{2} \mathrm{O}_{3}$ ultrafine and nano-particles no intermetallic reactions or presence of $\mathrm{Ca}$ and $\mathrm{Si}$ were observed. However, as already mentioned the distribution of particles was more homogeneous.

\subsection{Transmission electron microscopy (TEM)}

In the context of the microstructural changes a characterization and analysis of the ceramic particles incorporation in the steel matrix transmission electron microscopy (TEM) was also employed. With STEM/EDS elemental mapping shown in the Figure 17 and STEM line profile analysis shown in the Figure $\mathbf{1 8}$ successful incorporation and coherent bonding of the $\mathrm{Al}_{2} \mathrm{O}_{3}$ nanoparticles in the steel matrix was confirmed. No discontinuities at the particle/matrix interface, modification of metal matrix or formation of intermetallic phases could be observed.

\subsection{Particles distribution}

The particle distribution analysis performed on the specimens from the first set of experiments revealed that $\mathrm{Al}_{2} \mathrm{O}_{3}$ particles of $0.5 \%$ to $1.0 \%$ of mass fractions, regardless of the mean particle size of $500 \mathrm{~nm}$ or $50 \mathrm{~nm}$, results in a relatively homogeneous distribution of $\mathrm{Al}_{2} \mathrm{O}_{3}$ particles throughout the volume of the cast ingot. For low particle weight percents of $0.5 \%$ and $1.0 \%$ the distribution of $\mathrm{Al}_{2} \mathrm{O}_{3}$ particles in the cast ingot was found to be more or less independent on the position, concentration and size of particles, resulting in about 0.01 particles $/ \mu \mathrm{m}^{2}$. However, as the weight percent increased to 2.5 the particle concentration ratio starts to decrease toward the bottom of the cast ingot (Figure 19). Furthermore, with the increased particle mass fraction, also their concentration in cast ingot increased by up to 3 times, with the size of particles starting to play a role. The larger the particles the larger is the volume fraction of the incorporated particles.

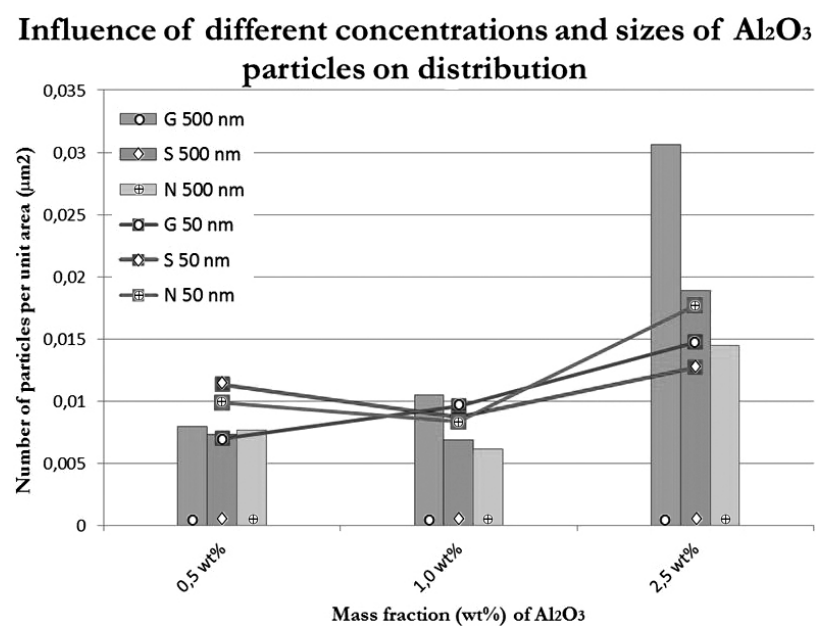

Figure 19: Influence of different concentrations and size of $\mathrm{Al}_{2} \mathrm{O}_{3}$ particles on their distribution in the cast ingot

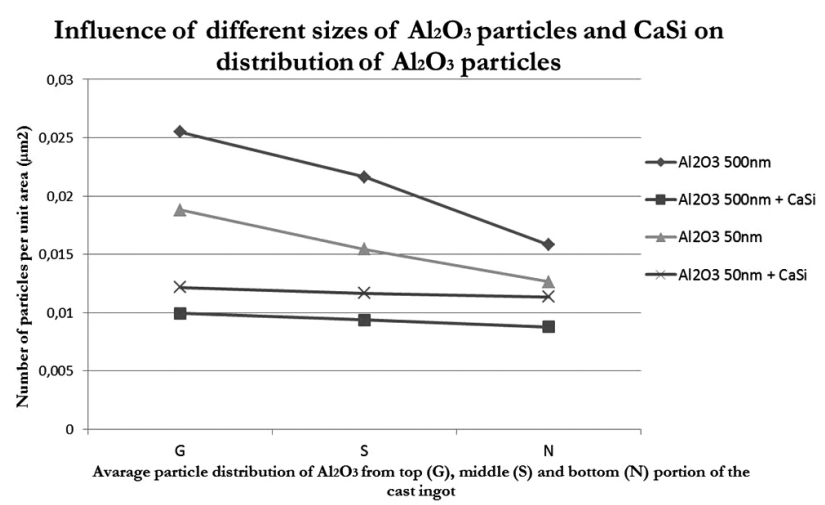

Figure 20: Influence of different sizes of $\mathrm{Al}_{2} \mathrm{O}_{3}$ particles and $\mathrm{CaSi}$ on distribution of $\mathrm{Al}_{2} \mathrm{O}_{3}$ particles $(1 \%)$

The particles distribution analysis from the second set of experiments (Figure 20) shows that the use of dispersion agent reduces the influence of particles size (500 $\mathrm{nm}$ or $50 \mathrm{~nm}$ ) on the particles' distribution in the steel matrix. It results in a difference in the particles' concentration throughout the ingot being reduced from about 0.01 particles $/ \mu \mathrm{m}^{2}$ to less than 0.002 particles $/ \mu \mathrm{m}^{2}$.

\section{CONCLUSIONS}

The results of our investigation indicate that steel reinforced with ceramic ultrafine/nanosized particles can be produced by using a conventional casting route. Ultrafine particles and nanoparticles where successfully incorporated into the steel matrix, being confirmed by different analysing techniques, including light microscopy (LM), scanning electron microscopy (SEM), Auger electron spectroscopy (AES) techniques and transmission electron microscopy (TEM).

By using CaSi as a dispersion media and introducing $\mathrm{Al}_{2} \mathrm{O}_{3} / \mathrm{CaSi}$ mixture through a sealed iron tube reduced 
particles clustering and more homogeneous distribution of reinforcement nanoparticles in the steel matrix were obtained. It was found that the concentration and the size of particles have an impact on the distribution of the reinforcement within the matrix. When the weight percent is increased above 1.0 it starts to affect the particles' distribution, with the concentration ratio decreasing towards the bottom of the cast ingot. In this case also the size of the particles plays a role: a larger particle size leading to an increased degree of incorporated particles in the steel matrix.

In this study, an innovative pre-dispersion approach for more the effective addition of ultrafine particles and nanoparticles into a steel melt through a conventional casting route was designed. It is based on mixing ultrafine particles and nanoparticles powder with dispersion media.

\section{Acknowledgment}

This work was done in the frame of the research programs P2-0050, which are financed by the Slovenian Research Agency. The authors would also like to acknowledge help from Miroslav Pečar, inž., from Institute of Metals and Technology for the AES analysis.

\section{REFERENCES}

${ }^{1}$ R. Casati, M. Vedani, Metal Matrix Composites Reinforced by Nano-Particles - A Review, Metals (Basel), 4 (2014) 1, 65-83, doi: 10.3390/met4010065

${ }^{2}$ S. H. Lee, J. J. Park, S. M. Hong, B. S. Han, M. K. Lee, C. K. Rhee, Fabrication of cast carbon steel with ultrafine TiC particles. Trans Nonferrous Met Soc China (English Ed.) 21 (2011), 54-57, doi:10.1016/S1003-6326(11)61060-1

${ }^{3}$ Y. Q. Liu, H. T. Cong, W. Wang, C. H. Sun, H. M. Cheng, AlN nanoparticle-reinforced nanocrystalline Al matrix composites: Fabrication and mechanical properties. Met.Sic.Eng.A, 505 (2009), 151-156, doi:10.1016/j.msea.2008.12.045

${ }^{4}$ Z. Zhang, L. D. Chen, Consideration of Orowan strengthening effect in particulate-reinforced metal matrix nanocomposites: A model for predicting their yield strength. Scripta Mater., 54 (2006), 1321-1326, doi:10.1016/j.scriptamat.2005.12.017

${ }^{5}$ J. Llorca, Fatigue of particle-and whisker reinforced metal-matrix composites. Prog Mater Sci., 47 (2002), 283-353, doi:10.1016/ S0079-6425(00)00006-2

${ }^{6}$ B. N. Chawla, Y. Shen, Mechanical Behavior of Particle Reinforced Metal Matrix Composites **. Adv Eng Mater., 3 (2001) 6, 357-370, doi:10.1002/1527-2648(200106)3:6<357::AID-ADEM357>3.3.CO;2-9

${ }^{7}$ Z. Ni, Y. Sun, F. Xue, J. Bai, Y. Lu, Microstructure and properties of austenitic stainless steel reinforced with in situ TiC particulate,Mater. Des., 32 (2011) 3, 1462-1467, doi:10.1016/j.matdes.2010.08.047

${ }^{8}$ F. Akhtar, Ceramic reinforced high modulus steel composites: processing, microstructure and properties,Can. Metall. Q., 53 (2014) 3, 253-263, doi: 10.1179/1879139514Y.0000000135

${ }^{9}$ S-Y.Cho, J-H. Lee, Anisotropy of wetting of molten $\mathrm{Fe}$ on $\mathrm{Al}_{2} \mathrm{O}_{3}$ single crystal. Korean J Mater Res., 18 (2008) 1, 18-21, doi:10.3740/ MRSK.2008.18.1.018

${ }^{10}$ R. V. Väinölä, L. E. K. Holappa, P. H. J. Karvonen, Modern steelmaking technology for special steels, Journal of Materials Processing Technology, 53 (1995), 453-465, doi:10.1016/0924-0136(95) 02002-4 